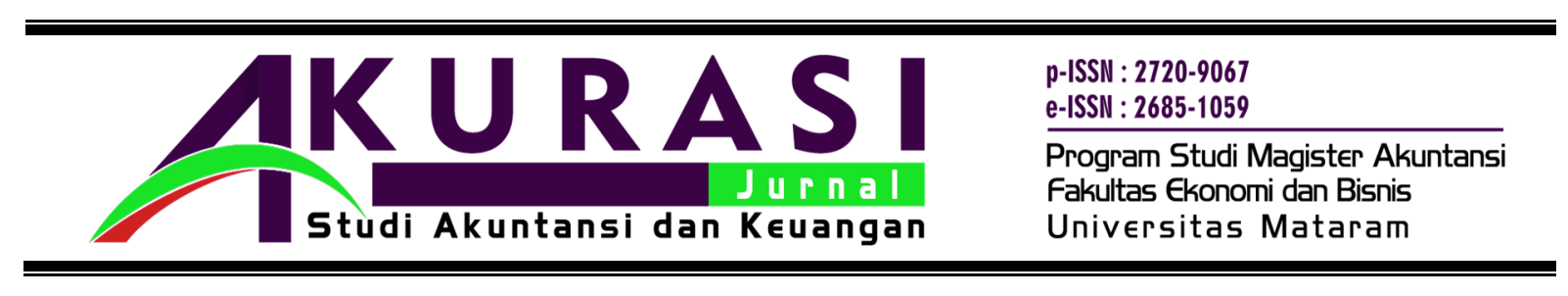

\title{
PENGARUH LEVERAGE, CAPITAL INTENSITY, KOMISARIS INDEPENDEN DAN KEPEMILIKAN INSTITUSIONAL TERHADAP TAX AVOIDANCE
}

\author{
Sevi Lestya Dewi ${ }^{1}$, Rachmawati Meita Oktaviani ${ }^{2}$ \\ Universitas Stikubank Semarang, Indonesia \\ ${ }^{12}$ Corresponding author : sevilestya119@gmail.com
}

INFORMASI ARTIKEL

Article history:

Dikirim tanggal: 18-10-2021

Revisi pertama tanggal: 26-10-2021

Diterima tanggal: 03/11/2021

Tersedia online tanggal 27/12/2021

\section{ABSTRAK}

Penelitian ini bertujuan untuk menganalisis pengaruh leverage, capital intensity, komisaris independen, dan kepemilikan institusional terhadap tax avoidance. Penelitian ini termasuk penelitian kuantitatif dengan menggunakan data sekunder yang diperoleh dari laporan tahunan perusahaan. Populasi dari penelitian ini adalah perusahaan manufaktur yang terdaftar di Bursa Efek Indonesia (BEI) tahun 2016-2020. Sebanyak 75 sampel dipilih dengan metode purposive sampling, dan dianalisis menggunakan regresi data panel. Hasil penelitian menunjukkan bahwa komisaris independen berpengaruh signifikan negatif terhadap tax avoidance, sedangkan leverage, capital intensity, dan kepemilikan institusional tidak berpengaruh signifikan terhadap tax avoidance. Hasil penelitian mengimplikasikan peran pengawasan dan monitoring dalam menerapkan perencanaan pajak perusahaan yang optimal untuk menurunkan tingkat tax avoidance.

Kata Kunci: tax avoidance, leverage, capital intensity, komisaris independen, kepemilikan institusional

\begin{abstract}
This study aims to analyze the effect of leverage, capital intensity, independent commissioners, and institutional ownership on tax avoidance. This research includes quantitative research using secondary data obtained from the company's annual report. The population of this study is manufacturing companies listed on the Indonesia Stock Exchange (IDX) in 2016-2020. Seventy-five samples were selected by the purposive sampling method and analyzed using panel data regression. The results showed that independent commissioners had a significant negative effect on tax avoidance, while leverage, capital intensity, and institutional ownership had no significant effect on tax avoidance. The study results imply the role of supervision and monitoring in implementing optimal corporate tax planning to reduce tax avoidance.
\end{abstract}

Keywords: tax avoidance, leverage, capital intensity, independent commissioner, institutional ownership 


\section{Pendahuluan}

Pajak merupakan salah satu hal yang penting bagi negara untuk menopang anggaran dan membantu pembiayaan pembangunan dalam negeri. Sifat pajak adalah memaksa seluruh warga negara dan tidak mendapatkan imbalan secara langsung. Wajib pajak yang patuh dalam pembayaran pajaknya akan membantu perekonomian negara. Upaya pemerintah dalam memaksimalkan jumlah pajak yang diterima negara guna meningkatkan perekonomian negara, sementara perusahaan memiliki tujuan agar pembayaran pajak rendah agar laba yang diperoleh maksimal (Oliviana dan Muid, 2019). Fungsi pajak menurut Halim et al. (2020: 4) digunakan sebagai fungsi budgetair dan fungsi mengatur (regulerend). Fungsi budgetair digunakan untuk pembiayaan pemerintah dan fungsi mengatur untuk mengatur masyarakat untuk melaksanakan kebijakan yang ada. Salah satu cara untuk mengetahui kinerja pajak adalah dengan tax ratio. Tabel 1 berikut menyajikan tentang tax ratio Indonesia dalam 5 tahun terakhir:

Tabel 1. Tax Ratio Indonesia Tahun 2016-2020.

\begin{tabular}{lc}
\hline Tahun & Tax Ratio \\
\hline 2016 & $10,8 \%$ \\
2017 & $10,7 \%$ \\
2018 & $11,4 \%$ \\
2019 & $11,1 \%$ \\
2020 & $11,6 \%$ \\
\hline
\end{tabular}

Sumber: Informasi APBN 2020

Tax ratio yang rendah menggambarkan bahwa kesadaran wajib pajak dalam membayar pajak masih rendah. Penerimaan pajak yang masih rendah ini dapat disebabkan karena adanya tax avoidance atau penghindaran pajak. Terjadinya tax avoidance dikarenakan tujuan antara pemerintah dan perusahaan bertolak belakang (Yuni dan Setiawan, 2019). Selain itu, tax avoidance dapat terjadi karena sistem pemungutan pajak di Indonesia menggunakan self assessment system. Penyimpangan pajak yang diyakini paling rentan dikarenakan sistem pemungutan self assessment system (Apsari dan Supadmi, 2018). Menurut Ayuningtyas dan Sujana (2018) tax avoidance adalah cara untuk mengurangi beban pajak yang dilakukan secara legal dan tidak menimbulkan bahaya bagi wajib pajak, akan tetapi hal ini dapat menjadi risiko perusahaan yang menimbulkan sanksi, denda, dan citra perusahaan yang memburuk di mata masyarakat. Walaupun tax avoidance adalah tindakan legal tetapi tidak disarankan oleh pemerintah. Faktor yang dapat mempengaruhi tax avoidance berdasarkan hasil riset terdahulu antara lain adalah leverage, capital intensity (intensitas modal), komisaris independen, dan kepemilikan institusional.

Leverage dapat menjadi salah satu indikasi perusahaan melakukan tindakan tax avoidance (Sinaga dan Suardikha, 2019). Leverage adalah rasio yang digunakan sebagai alat ukur perusahaan dalam mengukur pemenuhan kewajiban jangka panjangnya. Rasio perusahaan yang digunakan untuk mengukur aktiva yang dibiayai oleh utang disebut dengan leverage (Pratiwi dan Oktaviani, 2021). Perusahaan yang memiliki rasio utang tinggi akan cenderung rendah dalam pembayaran pajaknya. Perusahaan yang menggunakan utang akan menambah beban bunga dan mengurangi beban pajak 
perusahaan yang harus dibayarkan. Leverage diproksikan oleh DER (Debt to Equity Ratio). Untuk mencari keuntungan atau manfaat perusahaan akan memanfaatkan rasio utang. Penelitian terdahulu yang berkaitan dengan leverage telah dilakukan oleh beberapa peneliti. Hasil penelitian Antari dan Setiawan (2020) menyebutkan bahwa leverage berpengaruh positif yang juga dinyatakan oleh Oktaviani et al. (2021) dan sejalan dengan penelitian Widodo dan Wulandari (2021). Hasil penelitian Masrurroch et al. (2021) menyebutkan bahwa leverage tidak berpengaruh terhadap tax avoidance yang sejalan dengan penelitian dari Triyanti et al. (2020) serta Sinaga dan Suardikha (2019). Hasil ini bertolak belakang dengan penelitian Prasatya et al. (2020) yang menjelaskan bahwa leverage berpengaruh terhadap tax avoidance.

Faktor lain yang berkaitan dengan tax avoidance adalah capital intensity ratio atau rasio intensitas modal. Seberapa besar modal perusahaan yang dialokasikan ke aset tetap dalam rangka investasi disebut capital intensity (Rifai dan Atiningsih, 2019). Capital intensity ini dapat mempengaruhi beban penyusutan karena pada dasarnya aset tetap akan mengalami penyusutan pada setiap tahunnya sehingga dapat mengurangi beban pajak perusahaan. Beban pajak yang menurun dapat memaksimalkan laba yang perusahaan. Semakin besar ratio capital intensity maka akan semakin besar beban penyusutan dan tindakan tax avoidance juga akan semakin tinggi. Penelitian terkait dengan capital intensity dinyatakan oleh Masrurroch et al. (2021) bahwa capital intensity tidak berpengaruh terhadap tax avoidance, selaras dengan penelitian dari Saputri (2018) serta Yutaro dan Miftatah (2020). Berbeda dengan penelitian dari Zainuddin dan Anfas (2021) serta Sinaga dan Suardikha (2019) yang menyebutkan bahwa capital intensity berpengaruh negatif terhadap penghindaran pajak, yang sejalan dengan hasil studi Apsari dan Supadmi (2018). Sementara itu hasil capital intensity berpengaruh positif terhadap tax avoidance dinyatakan oleh Widodo dan Wulandari (2021) yang selaras dengan hasil studi Dwiyanti dan Jati (2019) bahwa capital intensity berpengaruh positif terhadap tax avoidance.

Karakteristik corporate governance yang turut diuji dalam penelitian ini adalah komisaris independen dan kepemilikan institusional. Corporate governance diyakini akan menciptakan lingkungan kerja yang sehat bahkan akan berkaitan dengan manajemen perpajakan. Komisaris independen pada suatu perusahaan akan berdampak positif terhadap kinerja dan nilai perusahaan (Zhou, 2011). Komisaris independen diyakini akan memberi pengawasan dalam suatu perusahaan untuk pengambilan keputusan, termasuk dalam bidang perpajakan. Komisaris independen tidak memiliki hubungan dengan perusahaan sehingga dapat menjadi pihak untuk mengawasi dan memonitor tindakan manajemen yang oportunistik. Penelitian terkait komisaris independen, dikemukakan oleh Sunarto et al. (2021) yang menyatakan bahwa komisaris independen tidak berpengaruh terhadap tax avoidance, sejalan dengan penelitian Triyanti et al. (2020). Hasil penelitian lain mengungkapkan bahwa komisaris independen berpengaruh positif terhadap tax avoidance (Masrurroch et al., 2021). Studi Putri et al. (2020) juga menyatakan bahwa komisaris independen berpengaruh terhadap tax avoidance, meskipun hasil ini kontradiktif dengan penelitian dari Saputri (2018) yang menjelaskan bahwa komisaris independen berpengaruh negatif terhadap tax avoidance selaras dengan penelitian.

Isu tax avoidance masih menarik untuk dikaji di Indonesia, karena tax avoidance dapat mengurangi beban pajak perusahaan tanpa melanggar hukum. Alasan menguji 
variabel kinerja keuangan berupa leverage dan capital intensity karena keduanya dapat mengurangi beban pajak, dengan memanfaatkan beban bunga dan depresiasi. Penggunaan kinerja keuangan berdasarkan pada UU Pajak penghasilan pasal 6 terkait dengan beban yang diperbolehkan (deductable expense). Selain kinerja keuangan, tata kelola perusahaan yang baik juga berperan yang diproksikan dengan komisaris independen dipercaya dapat memantau perilaku oportunistik manajemen.

Hasil penelitian sebelumnya menunjukkan adanya kontradiksi dalam hasil penelitian mengenai leverage, capital intensity, dan komisaris independen terhadap tax avoidance dan memiliki keterbatasan pada variabel yang diuji. Oleh karena itu, variabel-variabel tersebut perlu untuk diuji kembali untuk memberikan bukti empiris baru dengan menambahkan variabel kepemilikan institusional yang merupakan salah satu komponen good corporate governance. Kepemilikan institusional merupakan salah satu komponen dari good corporate governance. Kepemilikan institusional merupakan kepemilikan saham yang dimiliki oleh pemerintah atau instansi lain seperti bank, perusahaan asuransi, perseroan terbatas dan lainnya (Yuni dan Setiawan, 2019). Kepemilikan institusional dapat menjadi pengawas kinerja manajemen agar lebih efektif dalam pekerjaannya karena mampu memantau setiap keputusan manajemen (Arianandini dan Ramantha, 2018). Proporsi kepemilikan institusional dapat berpengaruh terhadap kebijakan pajak perusahaan.

Beberapa penelitian menguji keterkaitan kepemilikan institusional terhadap tax avoidance. Hasil penelitian dari Yuni dan Setiawan (2019) menyatakan bahwa kepemilikan institusional berpengaruh negatif terhadap tax avoidance, sedangkan Arianandini dan Ramantha (2018) dan Zainuddin dan Anfas (2021) menyebutkan bahwa kepemilikan institusional tidak berpengaruh terhadap tax avoidance. Kontradiktif dengan hasil studi sebelumnya, penelitian Sunarto et al. (2021) mengungkapkan bahwa kepemilikan institusional berpengaruh positif terhadap tax avoidance. Penelitian ini juga menggunakan profitabilitas sebagai variabel kontrol untuk menghindari masalah endogenitas. Profitabilitas adalah salah satu cara perusahaan dalam menunjukkan kemampuan untuk mendapatkan keuntungan selama periode tertentu dengan tingkat penjualan, aset, dan stok modal tertentu (Anggraeni \& Oktaviani, 2021). Hasil pengujian dalam penelitian dengan menggunakan data panel yaitu kombinasi antara data time series dan cross section menunjukkan bahwa model Fixed Effect Model (FEM) merupakan model yang terbaik untuk digunakan. Penelitian ini memberikan kontribusi tentang pentingnya pengawasan dan monitoring terhadap perencanaan pajak yang optimal untuk menurunkan tingkat tax avoidance.

\section{Kerangka Teoretis dan Pengembangan Hipotesis}

Agency theory yang dikemukakan Jensen \& Meckling (1976) menjelaskan hubungan antara pemegang saham dan pengelola perusahaan. Teori ini mengargumentasikan hubungan kerjasama antara dua belah pihak berdasarkan kontrak yaitu antara pemberi wewenang dengan yang diberi wewenang, untuk mengambil keputusan-keputusan terkait operasional perusahaan. Pengelola perusahaan cenderung lebih banyak memiliki informasi perusahaan yang mengakibatkan adanya masalah agensi dan biaya agensi (Handayani dan Ibrani, 2019). Teori ini berhubungan dengan tax avoidance dikarenakan perusahaan yang memiliki pengelolaan yang kurang baik akan berdampak pada citra perusahaan. 
Leverage merupakan salah satu gambaran sebuah perusahaan terkait dengan keputusannya dalam pendanaan. Rasio leverage yang semakin besar mengindikasikan utang yang digunakan perusahaan semakin besar dan akan semakin besar pula beban bunga yang timbul (Sinaga dan Suardikha, 2019). Hal ini akan menyebabkan tingkat tax avoidance akan semakin tinggi. Berdasarkan teori agensi, principal dan agent akan lebih mementingkan ego masing-masing dan akan berbuat agar dirinya merasa sejahtera. Salah satu tindakan yang dapat dilakukan adalah dengan menggunakan rasio leverage untuk mempengaruhi beban bunga perusahaan. Hal ini karena meningkatnya beban bunga akan menyebabkan pajak yang dibayarkan rendah (Oktaviani et al., 2021). Hasil penelitian terdahulu yang dilakukan oleh Sinaga dan Suardikha (2019) menunjukkan bahwa leverage berpengaruh positif terhadap tax avoidance, penelitian dengan hasil yang sejalan juga diungkapkan oleh Antari dan Setiawan (2020). Hal ini berarti semakin tinggi tingkat utang perusahaan untuk pembiayaan operasional maka tingkat tax avoidance akan semakin tinggi. Widodo dan Wulandari (2021) juga mengungkapkan bahwa leverage berpengaruh positif terhadap tax avoidance. Berdasarkan kajian teori agensi dan penelitian empiris sebelumnya menunjukkan adanya hubungan positif antara leverage dengan tax avoidance. Dengan demikian dapat hipotesis yang dirumuskan sebagai berikut:

$\mathrm{H}_{1}$ : Leverage berpengaruh positif terhadap tax avoidance.

Bentuk keputusan keuangan salah satunya ditunjukkan oleh adanya capital intensity (Gula dan Mulyani, 2020). Capital intensity menunjukkan perbandingan antara aset tetap dengan total aset perusahaan. Selain itu capital intensity akan menggambarkan sebuah perusahaan yang berinvestasi dengan menggunakan aset tetap yang dimiliki untuk memanfaatkan beban penyusutan. Semakin tinggi tingkat capital intensity maka akan semakin tinggi pula beban penyusutan dan akan mengurangi beban pajak yang akan dibayarkan oleh perusahaan (Saputri, 2018). Beban penyusutan ini dapat mengurangi laba perusahaan dan menyebabkan meningkatnya pula tindakan tax avoidance yang dilakukan. Jika dihubungkan dengan teori agensi adanya perbedaan kepentingan antara agent dan principal, menunjukkan bahwa agent akan memperoleh laba yang tinggi dan principal agak sedikit dalam pembayaran pajaknya. Adanya perbedaan kepentingan tersebut dapat memanfaatkan adanya beban penyusutan yang didapat dari aset tetap yang diinvestasikan.

Hasil studi sebelumnya mengungkapkan bahwa semakin tinggi tingkat capital intensity pada perusahaan akan semakin tinggi tingkat tax avoidance yang dilakukan. Hasil penelitian Widodo dan Wulandari (2021) menyatakan bahwa capital intensity berpengaruh positif terhadap tax avoidance. Pengaruh positif antara capital intensity dengan tax avoidance juga ditemukan oleh Dwiyanti dan Jati (2019). Sejalan dengan penelitian sebelumnya, Sinaga dan Suardikha (2019) juga menemukan hasil bahwa capital intensity berpengaruh positif terhadap tax avoidance. Berdasarkan argumentasi tersebut maka diajukan hipotesis sebagai berikut:

$\mathrm{H}_{2}$ : Capital intensity berpengaruh positif terhadap tax avoidance.

Komisaris independen dinilai memiliki pengawasan dan monitoring yang lebih luas terhadap manajemen yang menyangkut internal perusahaan (Sinaga dan Suardikha, 2019). Komisaris independen diharapkan mampu untuk membantu dalam pencegahan perilaku manajemen yang bersikap oportunistik dan melakukan pengawasan termasuk dalam hal 
perpajakan perusahaan. Proporsi komisaris independen dapat tercermin dari CETR yang tinggi, sehingga dapat diketahui bahwa tindakan tax avoidance perusahaan akan rendah. Adanya komisaris independen diharapkan mampu untuk meminimalisir tingkat konflik keagenan yang terjadi. Hubungan komisaris independen dengan penghindaran pajak dinyatakan pada penelitian Yuni dan Setiawan (2019) yang mengungkapkan bahwa komisaris independen berpengaruh negatif terhadap tax avoidance. Semakin banyak proporsi komisaris independen maka akan semakin kecil tingkat tindakan tax avoidance. Hasil penelitian Saputri (2018) juga menyebutkan bahwa komisaris independen berpengaruh negatif terhadap tax avoidance. Dengan demikian dapat diajukan hipotesis sebagai berikut:

$\mathrm{H}_{3}$ : Komisaris independen berpengaruh negatif terhadap tax avoidance

Kepemilikan institusional memiliki arti penting dalam mengawasi tindakan manajemen yang oportunistik (Wijayanti dan Lely, 2017). Kepemilikan institusional akan mengawasi perilaku manajemen agar bertindak secara efektif dan berhati-hati saat mengambil keputusan. Kepemilikan institusional dalam suatu perusahaan dapat mempengaruhi tindakan meminimalkan beban pajak yang dilakukan oleh perusahaan (Zainuddin dan Anfas, 2021). Tingginya tingkat kepemilikan institusional akan dapat meminimalisir tingkat tax avoidance. Hal ini dianggap dapat mengurangi konflik dari teori agensi yang mengatakan bahwa agent dan prinsipal akan memiliki kepentingan yang berbeda dan dengan adanya kepemilikan institusional ini dianggap dapat mengontrol dan mengurangi konflik keagenan yang ada. Studi sebelumnya yang dilakukan Yuni dan Setiawan (2019) menyatakan bahwa kepemilikan institusional berpengaruh negatif terhadap tindakan tax avoidance. Semakin tinggi kepemilikan institusional maka akan semakin rendah tingkat tax avoidance yang dilakukan perusahaan. Berdasarkan argumnetasi tersebut maka dapat dirumuskan hipotesis sebagai berikut:

$\mathrm{H}_{4}$ : Kepemilikan institusional berpengaruh negatif terhadap tax avoidance.

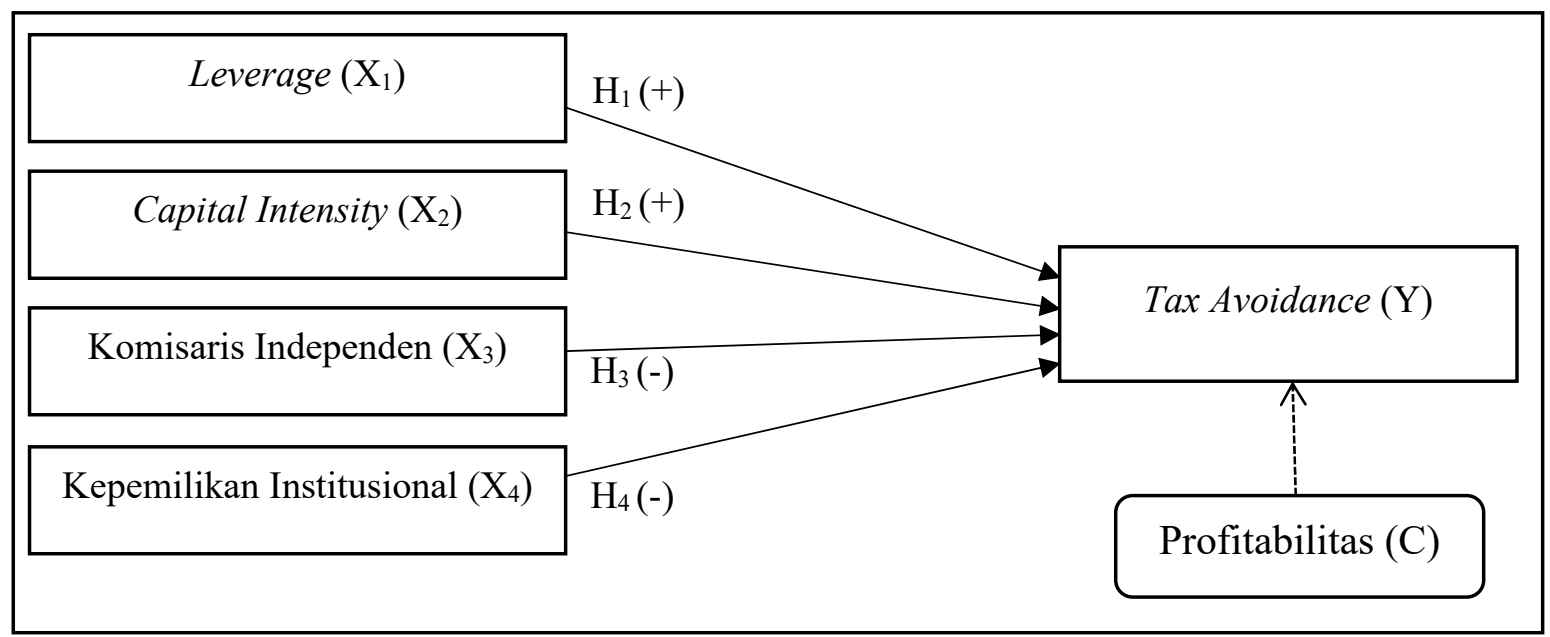

Gambar 1. Model Penelitian 


\section{Metode Penelitian}

Penelitian ini merupakan penelitian kuantitatif yang menggunakan data sekunder perusahaan manufaktur yang terdaftar di Bursa Efek Indonesia periode 2016-2020. Sampel dalam penelitian ini sejumlah 75 perusahaan yang diambil menggunakan teknik purposive sampling dengan kriteria sebagai berikut: (1) perusahaan yang menggunakan mata uang rupiah sebagai mata uang dalam laporan keuangan, (2) perusahaan yang mempublikasikan annual report berturut-turut, (3) perusahaan yang tidak mengalami kerugian pada periode pengamatan, (4) memiliki nilai CETR 0 s.d $>1$, (5) perusahaan yang tidak memiliki restitusi atau pengembalian pajak, (6) dan perusahaan yang menggunakan akhir periode 31 Desember pada laporan keuangannya.

Variabel dependen pada penelitian ini merupakan tax avoidance. Tax avoidance merupakan cara meminimalkan beban pajak dengan cara legal dan tidak melanggar undang-undang (Sinaga dan Suardikha, 2019). Tax avoidance dalam penelitian ini diukur menggunakan CETR atau Cash Effective Tax Rate. Rasio ini diukur dengan membagi antara pembayaran pajak penghasilan dengan cash dibagi dengan laba sebelum pajak. Perhitungan CETR merujuk pada penelitian Chen et al. (2010) yang dihitung dengan rumus sebagai berikut :

$$
\text { CETR }=\frac{\text { Pembayaran Pajak Penghasilan dengan Cash }}{\text { Laba Sebelum Pajak }}
$$

Variabel independen pada penelitian ini adalah leverage (X1), capital intensity (X2), komisaris independen (X3), dan kepemilikan institusional (X4). Leverage merupakan tingkat utang perusahaan yang digunakan untuk biaya operasional dengan Debt to Aset Ratio (DAR) digunakan sebagai proksi penelitian. Perhitungan rasio leverage terdapat pada penelitian (Sinaga dan Suardikha, 2019). Adapun perhitungan DAR dapat menggunakan rumus sebagai berikut:

$$
\text { DAR }=\frac{\text { Total Liabilitas }}{\text { Total Aset }} \times 100 \%
$$

Variabel capital intensity merupakan tingkat modal yang diinvestasikan kepada aset tetap perusahaan untuk memberikan manfaat. Capital intensity merupakan rasio aktivitas investasi perusahaan yang berkaitan dengan aset tetap (Furi, 2018). Perhitungan rasio capital intensity merujuk pada penelitian Kalbuana et al. (2020) dengan membagi antara total aset tetap dengan total aset, yang dirumuskan sebagai berikut:

$$
C I=\frac{\text { Total Aset Tetap }}{\text { Total Aset }}
$$

Komisaris independen diharapkan mampu untuk mengontrol dan mengawasi pihak manajemen perusahaan. Proporsi komisaris independen dihitung dengan membagi total komisaris independen dengan total anggota dewan komisaris (Prasatya et al., 2020). Adapun perhitungan proporsi komisaris independen dengan rumus sebagai berikut: 


$$
\text { Kom. Ind }=\frac{\text { Jumlah Komisaris Independen }}{\text { Jumlah Anggota Dewan Komisaris }}
$$

Kepemilikan institusional merupakan seseorang yang memiliki pengawasan kinerja manajemen agar lebih maksimal dan dianggap mampu untuk memantau keputusan yang diambil pihak manajer agar lebih efektif dan berhati-hati (Arianandini dan Ramantha, 2018). Penelitian yang dilakukan Yuni dan Setiawan (2019) menggunakan perhitungan dengan membagi antara proporsi saham yang dimiliki institusi dengan jumlah saham yang diterbitkan. Adapun rumus yang digunakan sebagai berikut:

$$
\text { Kep.Ins }=\frac{\text { Jumlah Komisaris Independen }}{\text { Jumlah Anggota Dewan Komisaris }} \times 100 \%
$$

Profitabilitas adalah salah satu indikator untuk kinerja suatu perusahaan yang diukur dengan return on asset (ROA) (Anggraeni dan Oktaviani, 2021). Profitabilitas yang tinggi menandakan laba perusahaan yang didapat tinggi dan perusahaan efektif dalam melaksanakan kegiatan operasionalnya. Penelitian ini menggunakan proksi ROA yang merupakan perbandingan antara laba setelah pajak dengan total aset untuk menghitung variabel kontrolnya. Rumus yang digunakan seperti yang digunakan oleh Yuni \& Setiawan (2019) dengan rumus sebagai berikut:

$$
R O A=\frac{\text { Earning After Tax }(E A T)}{\text { Total Asset }}
$$

Model persamaan matematis regresi data panel yang diuji dalam penelitian ini adalah sebagai berikut.

\begin{tabular}{|c|c|}
\hline Y & $=$ Tax avoidance \\
\hline$\alpha$ & $=$ Konstanta \\
\hline $\mathrm{X}_{1}$ & $=$ Leverage \\
\hline $\mathrm{X}_{2}$ & $=$ Capital Intensity \\
\hline $\mathrm{X}_{3}$ & $=$ Komisaris Independen \\
\hline $\mathrm{X}_{4}$ & $=$ Kepemilikan Institusional \\
\hline $\mathrm{C}$ & $=$ Variabel Control \\
\hline$\varepsilon$ & $=$ Error \\
\hline
\end{tabular}

$$
Y=\alpha+\beta_{1} X_{1}+\beta_{2} X_{2}+\beta_{3} X_{3}+\beta_{4} X_{4}+C+\varepsilon
$$

Keterangan :

Analisis data dalam penelitian ini menggunakan metode regresi data panel dengan Common Effect model (CEM), Fixed Effect Model (FEM), dan Random Effect Model (REM). Analisis ini dilakukan untuk menguji pengaruh leverage, capital intensity, komisaris independen, dan kepemilikan institusional terhadap tax avoidance. Penelitian ini berjumlah sebanyak 75 observasi. Dalam pemilihan model dilakukan uji Chow dan uji Hausman. Uji chow bertujuan untuk penentuan model yang dipilih antara common effect model dengan fixed effect model. Hasilnya dilihat dari besarnya profitabilitas Crossselection F jika lebih kecil dari 0.05 maka menggunakan common effect model dan 
sebaliknya jika hasil menunjukkan lebih besar dari 0.05 maka menggunakan fixed effect model. Uji Hausman digunakan untuk penentuan model yang digunakan antara fixed effect model dengan random effect model. Apabila hasil dari nilai p-value lebih kecil dari 0.05 maka model yang digunakan adalah i, jika hasil menunjukkan lebih besar dari 0.05 menggunakan random effect model.

\section{Hasil dan Pembahasan}

Statistik deskriptif dan hasil pengujian regresi linier data panel serta robustness test dari penelitian ini didiskusikan pada bagian hasil dan pembahasan. Statistik deskriptif dari penelitian ini disajikan pada tabel 2 berikut ini:

Tabel 2. Uji Statistik Deskriptif

\begin{tabular}{|c|c|c|c|c|c|c|}
\hline & CETR & DAR & CIR & KOM. IND & KEP. INS & ROA \\
\hline Mean & 0.267733 & 0.360133 & 0.419600 & 0.460000 & 0.596667 & 11.55173 \\
\hline Median & 0.250000 & 0.350000 & 0.450000 & 0.500000 & 0.580000 & 9.570000 \\
\hline Maximum & 0.890000 & 0.820000 & 0.720000 & 0.800000 & 0.920000 & 46.30000 \\
\hline Minimum & 0.030000 & 0.120000 & 0.030000 & 0.290000 & 0.060000 & 0.050000 \\
\hline Std. Dev. & 0.125424 & 0.155576 & 0.130772 & 0.117623 & 0.247885 & 9.268936 \\
\hline Skewness & 1.801329 & 0.855658 & -0.202956 & 0.894657 & -0.812878 & 1794094 \\
\hline Kurtosis & 9.597835 & 3.766130 & 3.362362 & 4.612447 & 2.734342 & 6.488238 \\
\hline Jarque-Bera & 176.5956 & 10.98611 & 0.925219 & 18.13010 & 8.480178 & 78.25907 \\
\hline Probability & 0.000000 & 0.004115 & 0.629639 & 0.000116 & 0.014406 & 0.000000 \\
\hline Sum & 20.08000 & 27.01000 & 31.47000 & 34.50000 & 44.75000 & 866.3800 \\
\hline Sum Sq. Dev. & 1.164115 & 1.791099 & 1.265488 & 1.023800 & 4.547067 & 6357.575 \\
\hline Observations & 75 & 75 & 75 & 75 & 75 & 75 \\
\hline
\end{tabular}

Nilai CETR sebagai proksi dari tax avoidance dalam objek penelitian sangat bervariasi dengan nilai minimum CETR sebesar 0.03 yang terdapat pada PT Charoen Pokphand Indonesia Tbk di tahun 2016, sedangkan pada nilai maksimum sebesar 0.89 persen yang berada pada PT Chitose International Tbk tahun 2020. Rata-rata (mean) dalam variable tax avoidance menunjukkan angka 0.267733 yang berarti bahwa nilai rata-rata tax avoidance pada perusahaan yang digunakan sebagai sampel hanya sebesar 26.77 persen. Nilai median pada perusahaan sampel berada pada angka 0.25 persen, sementara itu nilai standar deviasi sebesar 0.125424 yang menunjukkan bahwa perbedaan nilai variabel yang terjadi pada tax avoidance dalam penelitian terhadap nilai rata-ratanya sebesar 12.54 persen. Nilai leverage atau yang diproksikan dengan Debt to Asset Ratio (DAR) menunjukkan nilai minimum sebesar 0.120000 atau 0.12 persen pada PT Ultra Jaya Milk Industry pada tahun 2016. Nilai maksimum sebesar 0.820000 atau 0.82 persen berada di PT Ultra Jaya Milk Industry tahun 2020 dan Ekadharma International Tbk tahun 2019 dan 2020. Rata rata pada pengujian sampel ini berada di angka 0.360133 yang menggambarkan bahwa rata-rata nilai leverage pada perusahaan yang digunakan sebagai sampel sebesar 36.01 persen. Nilai median pada perusahaan sampel menunjukkan angka 0.35 persen. Nilai standar deviasi sebesar 0.155576 , hal ini mencerminkan bahwa terjadi perbedaan nilai 
variable leverage dalam penelitian terhadap rata-rata sebesar 15.55 persen. Nilai capital intensity dalam pengujian ini menunjukkan nilai minimum sebesar 0.030000 atau 0.03 persen yang terletak pada Selamat Sempurna Tbk tahun 2016. Nilai maksimum ditunjukkan sebesar 0.720000 atau 0.72 persen yang terletak pada Semen Indonesia (Persero) Tbk tahun 2020. Nilai rata-rata yang dihasilkan dalam penelitian ini sebesar 0.419600 yang menunjukkan rata-rata capital intensity yang diwakilkan sampel perusahaan sebesar 41.96 persen. Nilai median yang ada pada hasil uji statistik ini sebesar 0.45 persen. Nilai standar deviasi sebesar 0.130772 yang menggambarkan bahwa terjadi perbedaan nilai variabel capital intensity dalam penelitian ini sebesar 13.07 persen.

Data statistik deskriptif untuk variabel komisaris independen menunjukkan nilai minimum sebesar 0.290000 atau 0.29 persen pada PT Semen Indonesia (Persero) Tbk pada tahun 2016 sampai dengan 2020. Nilai maksimum yang terletak pada PT Unilever Indonesia Tbk sebesar 0.800000 atau 0.80 persen pada tahun 2016 s.d 2020. Rata-rata yang dihasilkan dalam pengujian ini sebesar 0.460000 yang mencerminkan bahwa nilai rata-rata komisaris independen yang diwakili oleh sampel sebesar 46 persen. Nilai median yang ada dalam penelitian ini menunjukkan angka 0.50 persen, sedangkan untuk standar deviasi menunjukkan angka 0.117623 yang berarti terjadi perbedaan nilai variabel komisaris independen terhadap tax avoidance sebesar 11.76 persen. Pengujian statistik deskriptif dalam variabel kepemilikan institusional ini menunjukkan bahwa besarnya nilai minimum menunjukkan angka 0.06 persen yang ditunjukkan pada PT Charoen Pokphand Indonesia Tbk pada tahun 2016 sampai dengan 2020. Nilai maksimum berada di angka 0.92 persen yang terletak pada PT Akasha Wira International Tbk pada tahun 2016 s.d 2020. Nilai ratarata yang dihasilkan sebesar 0.596667 yang menandakan bahwa nilai rata-rata kepemilikan institusional yang diwakili oleh sampel perusahaan sebesar 59.66 persen. Nilai median yang muncul dalam pengujian sebesar 0.58 persen. Sementara itu, standar deviasi menunjukkan angka 0.247885 yang berarti terjadi perbedaan nilai variabel kepemilikan institusional terhadap tax avoidance sebesar 24.78 persen. Variabel kontrol profitabilitas menunjukkan nilai minimum sebesar 0.050000 pada PT Indofood Sukses Makmur Tbk pada tahun 2020, sedangkan nilai maksimum 46.30000 pada PT Unilever Indonesia Tbk pada tahun 2018. Nilai rata-rata sebesar 11.55173 yang menandakan bahwa nilai rata-rata profitabilitas yang diwakili oleh sampel sebesar 115.51 persen. Nilai median sebesar 9.570000, sedangkan standar deviasi menunjukkan angka 9.268936.

Hasil analisis regresi data panel disajikan pada Tabel 3. Nilai konstanta $(\alpha)$ pada hasil pengujian bernilai positif sebesar 0.242287 yang memiliki makna bahwa apabila variabel leverage, capital intensity, komisaris independen, dan kepemilikan institusional dinyatakan konstan pada angka nol, maka perusahaan akan cenderung melakukan tindakan penghindaran pajak atau tax avoidance. Selain itu tanpa adanya pengaruh apapun variabel tax avoidance akan meningkat sebesar 0.24 persen. Koefisien regresi $\left(\beta_{1}\right)$ sebesar negatif 0.070476 yang berarti bahwa apabila leverage meningkat sebesar 1 persen, maka tax avoidance akan menurun sebesar 0.07 persen dengan asumsi variabel lain konstan. Koefisien regresi $\left(\beta_{2}\right)$ sebesar 0.396251 yang berarti bahwa apabila capital intensity meningkat sebesar 1 persen, maka tax avoidance akan meningkat sebesar 0.396 persen dengan asumsi variabel lain konstan. Koefisien regresi $\left(\beta_{3}\right)$ sebesar -0.710646 yang berarti bahwa apabila komisaris independen meningkat sebesar 1 persen, maka tax avoidance 
akan menurun sebesar 0.71 persen dengan asumsi variabel lain konstan. Serta koefisien regresi $\left(\beta_{4}\right)$ sebesar 0.419582 yang berarti bahwa apabila kepemilikan institusional meningkat sebesar 1 persen, maka tax avoidance akan meningkat sebesar 0.419 persen dengan asumsi variabel lain konstan. Profitabilitas memiliki koefisien regresi sebesar negatif 0.003367 maka apabila profitabilitas meningkat sebesar 1 persen variabel tax avoidance akan menurun sebesar 0.003 persen.

Tabel 3. Hasil Uji Fixed Effect Model (FEM)

\begin{tabular}{lrrrr}
\hline \multicolumn{1}{c}{ Variable } & Coefficient & Std. Error & \multicolumn{1}{c}{ t-Statistic } & \multicolumn{1}{c}{ Prob. } \\
\hline C & 0.242287 & 0.404097 & 0.599575 & 0.5513 \\
Leverage & -0.070476 & 0.139135 & -0.506527 & 0.6145 \\
Capital Intensity & 0.396251 & 0.274317 & 1.444500 & 0.1543 \\
Komisaris Independen & -0.710646 & 0.263741 & -2.694489 & 0.0093 \\
Kepemilikan Institusional & 0.419582 & 0.549246 & 0.763924 & 0.4482 \\
Profitabilitas & -0.003367 & 0.003961 & -0.850116 & 0.0098 \\
\hline
\end{tabular}

Sumber: Data Diolah

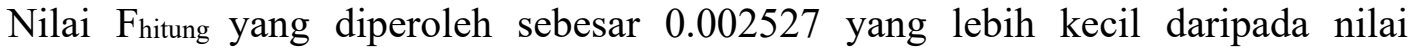
signifikasi 5\% ( $\mathrm{F}>0.05)$ yang menunjukkan bahwa secara bersama-sama variabel leverage, capital intensity, komisaris independen, dan kepemilikan institusional yang dikontrol oleh profitabilitas dalam penelitian ini dapat berpengaruh secara signifikan terhadap CETR sebagai proksi dari tax avoidance. Uji signifikansi parameter individul (uji t) menunjukkan bahwa hanya komisaris independen yang berpengaruh signifikan negatif terhadap tax avoidance, sedangkan hasil pengujian terhadap variabel independen lainnya seperti leverage, capital intensity dan kepemilikan institusional menunjukkan pengaruh yang tidak signifikan. Hasil pengujian terhadap variabel kontrol profitabilitas menunjukkan hasil signifikan negatif terhadap tax avoidance.

Tabel 4. Hasil Uji Robustness Test

\begin{tabular}{cccc}
\hline & Persamaan 1 & Persamaan 2 & Robustness test \\
\hline Adjusted R-Squared & 0.301381 & 0.297905 & 0.315516 \\
\hline
\end{tabular}

Robustness test merupakan uji ketahanan model. Berdasarkan Tabel 4 dapat diketahui bahwa ketahanan model yang dimiliki. Nilai Adjusted $R$-Squared persamaan 1 yaitu pengaruh leverage, capital intensity, komisaris independen, dan kepemilikan institusional terhadap tax avoidance sebesar 0.301381 atau 30.10 persen. Nilai Adjusted RSquared persamaan 2 yaitu pengaruh leverage, capital intensity, komisaris independen, dan kepemilikan institusional dan dikontrol oleh profitabilitas terhadap tax avoidance sebesar 0.297905 atau 29.79 persen. Nilai Adjusted R-Squared saat dilakukan Robustness Test menunjukkan angka 0.315516 atau 31.55 persen. Hasil saat sebelum dan sesudah ditambah variabel kontrol serta pada saat uji robustness tidak berubah secara signifikan. Hal ini menunjukkan bahwa data lolos pada saat uji ketahanan model.

Berdasarkan hasil uji signifikansi parameter individul pada pengujian olah data panel menunjukkan hasil bahwa variabel leverage (X1) memiliki nilai signifikasi sebesar 0.048438 yang bernilai negatif dengan nilai probabilitasnya 0.7238 lebih besar dari 0.05 
(Sig $>\alpha$ ). Hal ini berarti hipotesis $1\left(\mathrm{H}_{1}\right)$ yang menyatakan leverage berpengaruh negatif terhadap tax avoidance ditolak, menggambarkan bahwa leverage tidak berpengaruh signifikan terhadap tax avoidance. Semakin tinggi atau rendah tingkat utang tidak akan berpengaruh terhadap tindakan tax avoidance yang dilakukan oleh perusahaan. Semakin tinggi tingkat utang perusahaan maka manajemen akan cenderung berhati-hati dan tidak akan mengambil risiko yang dapat membahayakan perusahaan dengan tindakan tax avoidance (Arianandini dan Ramantha, 2018). Leverage merupakan tingkat utang yang digunakan perusahaan untuk membiayai operasionalnya. Penggunaan utang akan menimbulkan beban bunga yang akan mengurangi beban pajak yang akan dibayarkan oleh perusahaan. Jika dikaitkan dengan teori agensi, perusahaan menggunakan rasio hutang agar dapat manfaat dari laba yang tinggi sesuai kepentingan principal tanpa adanya tujuan untuk menghindari pajak. Beban bunga yang timbul tidak selalu akan menjadi pengurang laba sebelum pajak. Hal ini dapat mengurangi konflik dari teori agensi. Menurut peraturan pemerintah mengenai perpajakan, perbandingan antara rasio utang dan modal pada satu periode tidak boleh lebih dari peraturan yang ditetapkan yaitu sebesar 4:1. Jika melebihi rasio yang telah ditetapkan maka akan ada perhitungan kembali mengenai beban pajak sesuai dengan Peraturan Dirjen Pajak Nomor 25/PJ/2017. Dengan demikian dapat disimpulkan bahwa rasio leverage tidak mempengaruhi tindakan tax avoidance. Hasil ini sejalan dengan penelitian yang dilakukan oleh Susanti (2018) serta Arianandini dan Ramantha (2018) yang menyatakan bahwa leverage tidak berpengaruh terhadap tax avoidance. Selain itu hasil penelitian dari Rifai dan Atiningsih (2019), Zainuddin dan Anfas (2021) serta Masrurroch et al. (2021) juga menyebutkan bahwa leverage tidak berpengaruh terhadap tindakan tax avoidance.

Berdasarkan hasil pengujian olah data panel menunjukkan hasil bahwa capital intensity memiliki nilai signifikasi sebesar 0.441292 yang bernilai positif dengan probabilitas 0.1059 yang menunjukkan lebih besar dari $0.05(\mathrm{Sig}>\alpha)$. Hal ini berarti hipotesis $2\left(\mathrm{H}_{2}\right)$ yang menyatakan bahwa capital intensity berpengaruh negatif terhadap tax avoidance ditolak dan capital intensity tidak berpengaruh signifikan terhadap tax avoidance. Hasil analisis tidak mengonfirmasi teori keagenan yang menyebutkan bahwa modal yang di investasikan ke dalam asset tetap dapat mengatasi konflik yang terjadi antara pemilik saham dengan manajemen perusahaan. Penyebabnya adalah karena perusahaan yang ada di Indonesia memiliki asset tetap yang sudah melewati batas waktu yang ditetapkan oleh undang-undang perpajakan (Furi, 2018). Aset tetap yang sudah melewati batas umur tidak akan dapat disusutkan dan tidak akan menjadi pengurangan laba sebelum pajak. Dalam hal ini capital intensity tidak digunakan sebagai upaya dalam menghindari pajak tetapi hanya untuk pembiayaan perusahaan dalam aktivitas operasinya. Dengan demikian capital intensity akan menjadi alat untuk mendongkrak laba perusahaan tetapi jika tidak dapat memaksimalkan depresiasi tidak dapat digunakan untuk penghindaran pajak. Hasil penelitian ini sejalan dengan penelitian yang dilakukan oleh Yutaro dan Miftatah (2020) yang menunjukkan bahwa capital intensity tidak berpengaruh terhadap tindakan tax avoidance. Hasil penelitian ini juga sejalan dengan penelitian yang dilakukan Furi (2018) serta Masrurroch et al. (2021) dan Saputri (2018) bahwa variabel capital intensity tidak memiliki pengaruh terhadap tax avoidance. 
Hasil pengujian data panel menunjukkan hasil bahwa variabel komisaris independen memiliki nilai signifikasi -0.708905 yang bernilai negatif dengan tingkat probabilitas sebesar 0.0093 atau (Sig $<\alpha$ ). Hal ini menyatakan bahwa komisaris independen berpengaruh signifikan negatif terhadap tax avoidance sehingga hipotesis 3 $\left(\mathrm{H}_{3}\right)$ diterima. Semakin tinggi proporsi komisaris independen, maka akan semakin rendah tingkat tax avoidance yang dilakukan oleh perusahaan. Hal ini menjelaskan teori agensi dikarenakan dapat mengurangi konflik agensi antara pemegang saham dengan manajemen perusahaan. Manajemen cenderung akan lebih berhati-hati terhadap keputusan yang diambil termasuk keputusan mengenai perpajakan, karena adanya pengawasan dari komisaris independen yang ketat. Semakin meningkatnya proporsi komisaris independen dapat meminimalisir adanya tindakan tax avoidance. Dalam penelitian ini diungkapkan bahwa komisaris independen berpengaruh negatif terhadap tax avoidance perusahaan. Dengan demikian, hasil penelitian ini sejalan dengan studi Yuni dan Setiawan (2019) yang menyatakan bahwa komisaris independen berpengaruh negatif terhadap tax avoidance. Temuan ini juga sejalan dengan penelitian Saputri (2018) juga menyebutkan bahwa komisaris independen berpengaruh terhadap tax avoidance.

Berdasarkan hasil pengujian data panel menunjukkan bahwa hasil variabel kepemilikan institusional memiliki nilai signifikasi sebesar 0.413863 yang bernilai positif dengan tingkat probabilitas sebesar 0.4532 atau ( $\mathrm{Sig}<\alpha$ ). Hal ini menyatakan bahwa hipotesis $4\left(\mathrm{H}_{4}\right)$ pada penelitian ditolak sehingga hasil penelitian ini mengkonfirmasi bahwa kepemilikan institusional tidak berpengaruh signifikan terhadap tindakan tax avoidance. Semakin tinggi atau rendahnya kepemilikan institusional tidak akan mempengaruhi tindakan tax avoidance perusahaan. Perusahaan bertanggung jawab atas pemilik saham sehingga pemilik institusional dapat memastikan kesejahteraan para pemilik saham (Arianandini dan Ramantha, 2018). Hasil dari penelitian tidak mengonfirmasi Teori Keagenan yang menyatakan bahwa kepemilikan institusional dapat mengontrol dan memonitor tindakan manajemen. Pemilik institusional tidak dapat dipastikan akan menjadi pengendali untuk mengontrol perusahaan dengan baik atas tindakan yang dilakukan manajemen. Pemilik institusional yang tidak menjalani pengawasan dengan baik dapat berpotensi menyebabkan tax avoidance tetap terjadi. Kepemilikan institusional ini merupakan salah satu dari komponen Good Corporate Governance untuk mengawasi tindakan manajemen. Hasil penelitian ini sejalan dengan hasil penelitian Arianandini dan Ramantha (2018) yang menyebutkan bahwa kepemilikan institusional tidak berpengaruh terhadap tax avoidance. Penelitian lain juga diungkapkan Zainuddin dan Anfas (2021) serta Masrullah et al. (2018) bahwa kepemilikan institusional tidak berpengaruh terhadap tindakan tax avoidance.

\section{Kesimpulan, Implikasi dan Keterbatasan}

Penelitian ini dilakukan dengan tujuan menguji faktor-faktor yang mempengaruhi tindakan tax avoidance. Hasil pengujian menunjukkan bahwa proporsi komisaris independen berpengaruh signifikan negatif terhadap tax avoidance. Namun demikian hasil penelitian ini menyatakan bahwa leverage, capital intensity dan kepemilikan institusional tidak berpengaruh signifikan terhadap tax avoidance. Temuan ini mengimplikasikan bahwa ketika proporsi komisaris independen yang semakin meningkat maka akan 
mengurangi tindakan tax avoidance. Dengan demikian komisaris independen harus meningkatkan pengawasan dan monitoring kepada manajemen agar berdampak pada keputusan yang diambil terutama di bidang perpajakan. Temuan penelitian ini mengimplikasikan bahwa perusahaan harus menerapkan perencanaan pajak yang optimal agar dapat menurunkan tingkat tax avoidance. Perusahaan harus mengelola aset perusahaan berkaitan dengan capital instensity dengan semaksimal mungkin sehingga tidak akan berdampak pada tax avoidance. Selain itu untuk mengurangi dampak negatif tax avoidance, kepemilikan oleh institusional harus menjalankan tugas dan wewenang yang dimiliki agar manajemen tidak bertindak oportunistik demi kepentingan pribadi yang akan menimbulkan konflik agensi. Penelitian ini memiliki keterbatasan berkaitan dengan sampel penelitian, sehingga untuk peneliti selanjutnya diharapkan untuk memperluas kriteria sampel dan menggunakan sektor industri yang berbeda serta menambahkan variabel independen lain yang dapat mempengaruhi tindakan tax avoidance. Penelitian selanjutnya dapat mengelaborasi pengukuran lainnya sebagai proksi dari tax avoidance.

\section{Daftar Pustaka}

Anggraeni, T., \& Oktaviani, R. M. (2021). Dampak Thin Capitalization, Profitabilitas, Dan Ukuran Perusahaan Terhadap Tindakan Penghindaran Pajak. Jurnal Akuntansi dan Pajak, 21(02), 390-397.

Antari, N. W. D., \& Setiawan, P. E. (2020). Pengaruh Profitabilitas, Leverage dan Komite Audit pada Tax Avoidance. E-Jurnal Akuntansi, 30(10), 2591-2603.

Apsari, A. A. A. N. C., \& Supadmi, N. L. (2018). Pengaruh Kompensasi Eksekutif, Koneksi Politik, dan Capital Intensity pada Tax Avoidance. E-Jurnal Akuntansi, 25(2), $1481-1505$.

Arianandini, P. W., \& Ramantha, I. W. (2018). Pengaruh Profitabilitas, Leverage, dan Kepemilikan Institusional pada Tax Avoidance. E-Jurnal Akuntansi Universitas Udayana, 22(3), 2088-2116.

Ayuningtyas, N. P. W., \& Sujana, I. K. (2018). Pengaruh Proporsi Komisaris Independen, Leverage, Sales Growth, Dan Profitabilitas Pada Tax Avoidance. E-Jurnal Akuntansi Universitas Udayana, 25(3), 1884-1912.

Chen, S., Chen, X., Cheng, Q., \& Shevlin, T. (2010). Are Family Firms more Tax Aggressive than Non-family Firms? Journal of Financial Economics, 91(1), 41-61.

Dwiyanti, I. A. I., \& Jati, I. ketut. (2019). Pengaruh Profitabilitas, Capital Intensity, dan Inventory Intensity pada Penghindaran Pajak. E-Jurnal Akuntansi Universitas Udayana, 27(3), 2292-2321.

Furi, G. D. (2018). Pengaruh Leverage, Ukuran Perusahaan, Inventory Intensity, Capital Intensity Ratio, Sales Growth, dan Komisaris Independen Terhadap Tax Avoidance (Studi Empiris Pada Perusahaan Manufaktur yang Terdaftar di Bursa Efek Indonesia Tahun 2014-2016). Jom Feb, 1(1), 1-15.

Gula, V. E., \& Mulyani, S. D. (2020). Pengaruh Capital Intensity Dan Deferred Tax Expense Terhadap Tax Avoidance Dengan Menggunakan Strategi Bisnis Sebagai Variabel Moderasi. Prosiding Seminar Nasional Pakar Ke 3, 2.43.1-2.43.7. 
Halim, A., Bawono, I. R., \& Dara, A. (2020). Perpajakan Konsep, Aplikasi, Contoh, dan Studi Kasus (Edisi 3). Salemba Empat.

Handayani, Y. D., \& Ibrani, E. Y. (2019). Corporate Governance, Share Ownership Structure, And Tax Avoidance. International Journal of Commerce and Finance, 5(2), $120-127$.

Jensen, M. C., \& Meckling, W. H. (1976). Theory Of The Firm: Managerial Behavior, Agency Cost and Ownership Structure. Journal of Financial Economics 3, 3(4), 305360 .

Kalbuana, N., Solihin, Saptono, Yohana, \& Yanti, D. R. (2020). The Influence Of Capital Intensity, Firm Size, And Leverage On Tax Avoidance On Companies Registered In Jakarta Islamic Index ( Jii ) Period 2015-2019. International Journal of Economics, Business, and Accounting Research (IJEBAR), 4(3), 272-278.

Masrullah, Mursalim, \& Su'un, M. (2018). Pengaruh Kepemilikan Institusional, Komisaris Independen, Leverage Dan Sales Growth Terhadap Tax Avoidance Pada Perusahaan Manufaktur Di Bursa Efek Indonesia. Simak, 16(2), 142-165.

Masrurroch, L. R., Nurlaela, S., \& Fajri, R. N. (2021). Pengaruh profitabilitas, komsaris independen, leverage, ukuran perusahaan dan intensitas modal terhadap tax avoidance. I N O V a S I, 17(1), 82-93.

Oktaviani, R. M., Pratiwi, Y. E., Sunarto, S., \& Jannah, A. (2021). Apakah Leverage Dan Manajemen Laba Mempengaruhi Agresivitas Pajak? Proceeding SENDIU 2021, 349-355.

Oliviana, A., \& Muid, D. (2019). Pengaruh Good Corporate Governance Terhadap Tax Avoidance. Diponegoro Journal of Accounting, 8(3), 1-11.

Prasatya, R. E., Mulyadi, J., \& Suyanto, S. (2020). Karakter Eksekutif, Profitabilitas, Leverage, dan Komisaris Independen Terhadap Tax Avoidance Dengan Kepemilikan Institusional Sebagai Variabel Moderasi. Jurnal Riset Akuntansi \& Perpajakan (JRAP), 7(02), 153-162.

Pratiwi, Y. E., \& Oktaviani, R. M. (2021). Perspektif Leverage, Capital Intensity, dan Manajemen Laba Terhadap Tax Agreesiveness. Jurnal Akuntansi Dan Pajak, 22(1).

Putri, D. L., Rahmat, A., \& Aznuriyandi. (2020). Pengaruh Risiko Perusahaan, Proporsi Dewan Komisaris Independen, Komite Audit dan Konservatisme Akuntansi Terhadap Tax Avoidance Pada Perusahaan Manufaktur Yang Terdaftar Pada Bursa Efek Indonesia Tahun 2015-2017. Jurnal Akuntansi Kompetif, 3(1), 1-17.

Rifai, A., \& Atiningsih, S. (2019). Pengaruh Leverage, Profitabilitas, Capital Intensity, Manajemen Laba Terhadap Penghindaran Pajak. ECONBANK: Journal of Economics and Banking, 1(2), 135-142. https://doi.org/10.35829/econbank.v1i2.48

saputri, F. A. (2018). Pengaruh Profitabilitas, Leverage, Intensitas Modal Dan Proporsi Dewan Komisaris Independen Terhadap Tax Avoidance. Jurnal Ekobis Dewantara, 1(6), 171-180.

Sinaga, C. H., \& Suardikha, I. M. S. (2019). Pengaruh Leverage dan Capital Intensity pada Tax Avoidance dengan Proporsi Komisaris Independen sebagai Variabel Pemoderasi. E-Jurnal Akuntansi Universitas Udayana, 27(1), 1-32. 
Sunarto, S., Widjaja, B., \& Oktaviani, R. M. (2021). The Effect of Corporate Governance on Tax Avoidance: The Role of Profitability as a Mediating Variable. Journal of Asian Finance, Economics, and Business, 8(3), 217-227.

Susanti, C. M. (2018). Pengaruh Konservatisme, Leverage, Profitabilitas, Ukuran Perusahaan Terhadap Tax Avoidance. Jurnal Informasi, Perpajakan, Akuntansi, Dan Keuangan Publik, 13(2), 181-198.

Triyanti, N. W., Titisari, K. H., \& Dewi, R. R. (2020). Pengaruh Profitabilitas, Size, Leverage, Komite Audit, Komisaris Independen dan Umur Perusahaan terhadap Tax Avoidance. Jurnal Ilmiah Universitas Batanghari Jambi, 20(1), 113-120.

Widodo, sasongko wahyu, \& Wulandari, S. (2021). Pengaruh Profitabilitas, Leverage, Capital Intensity, Sales Growth dan Ukuran Perusahaan Terhadap Penghindaran Pajak. SIMAK, 19(1), 152-173.

Wijayanti, Y. C., \& Lely, N. K. (2017). Pengaruh Proporsi Komisaris Independen, Kepemilikan Institusional, Leverage, Dan Ukuran Perusahaan Pada Penghindaran Pajak. E-Jurnal Akuntansi Universitas Udayana, 20(1), 699-728.

Yuni, N. P. A. I., \& Setiawan, P. E. (2019). Pengaruh Corporate Governance dan Profitabilitas terhadap Penghindaran Pajak dengan Ukuran Perusahaan Sebagai Variabel Pemoderasi. E-Jurnal Akuntansi, 29(1), 128-144.

Yutaro, M. K. Z., \& Miftatah, D. (2020). Pengaruh corporate social responsibility, capital intensity dan kualitas audit terhadap penghindaran pajak. Jurnal Magister Akuntansi Trisakti, 7(1), 25-40.

Zainuddin, \& Anfas. (2021). Pengaruh Profitabilitas, Leverage, Kepemilikan Institusional Dan Capital Intensity Terhadap Penghindaran Pajak di Bursa Efek Indonesia. Journal of Economic, Public, and Accounting (JEPA), 3(2), 85-102.

Zhou, Y. (2011). Ownership structure, board characteristics, and tax aggressiveness. Thesis of Lingnan University. 